\title{
Životní způsob a jeho vybrané determinanty u dětí s onkologickým onemocněním
}

\section{The way of living and selected determinants of children with oncological diseases}

\author{
Tomáš Vyhlídal, Ondřej Ješina, Kateřina Holická \\ Fakulta tělesné kultury, Univerzita Palackého v Olomouci, \\ Česká republika
}

\section{Abstrakt:}

Déti a mládež s onkologickým onemocněním (OnOn) v době po intenzivni léčbě (tzv. obdobi remise) predstavuji skupinu se speciálními potřebami a problémy. Ty jsou nejčastěji bezprostředně spojené právě s léčbou OnOn. Patři mezi ně návrat mezi vrstevníky po dlouhodobém odloučeni, často ostych okoli a obavy z přjetí, formováni vlastni osoby v průběhu doby léčení, často změna hodnotového žebřičku, změna životního stylu apod. Právě proto, že životni zpưsob této cílové skupiny z pohledu determinant, které jej ovlivňují jako zásadní, je předmětem našeho zkoumání. Cílem našeho šetření je zjistit a popsat specifičnost konkrétních vybraných determinant pro budouci nápravu potenciálních rizik. Hlavním výzkumným nástrojem je dotazník označovaný jako disHBSC (,,dis“ označuje souhrnně skupinu osob se zdravotním postižením a zdravotním znevýhodněním; dále Health Behaviour of School-aged Children). Provedli jsme pilotní šetření u skupiny mládeže s OnOn, které nám poskytlo zajímavé výsledky pro dalši zpracování.

\section{Abstract:}

Children and young people with oncological diseases (OD) after intensive treatment (the so-called period of remission) are a group with special needs and problems. Those are the most immediately associated 
with the treatment of $O D$. Among the return among peers after the long separation, often shy around and concern with the adoption, the formation of private persons during the period of treatment, often changing the value system, a change of lifestyle, etc. Just because the way this audience with the perspective of the determinant, which affect it as essential, is the subject of our study. The aim of our investigation is to find out and describe the specificity of particular selected determinants for future remediation of potential risks. The main research instrument is the questionnaire known as the disHBSC ("dis" means a group of people with disabilities and health handicaps; Health Behaviour of School-aged Children). We conducted a pilot survey for youth groups with the OD, which are provided by the interesting results for further processing.

Kličová slova: aplikované pohybové aktivity, životni styl, zdraví, volný čas, kvalita života.

Key words: adapted physical activity, life style, health, leisure time, quality of life.

Př́spěvek je součástí projektu Krtek v siti, 22410220037.

\section{ÚVOD}

Ačkoliv se onkologická onemocnění (OnOn) řadí mezi nejobávanější choroby, vede moderní léčba dětí a mladých dospělých s onkologickým onemocněním v současné době k vyléčení zhruba 75-80 \% pacientů (Nadační fond dětské onkologie KRTEK, 2007). Onkologické onemocnění dítěte zasahuje zásadním způsobem do kvality života nejen nemocného, ale i celé jeho rodiny a přátel. Za důležité považujeme především to, že nemocný jedinec vnímá svou kvalitu života a mění svůj názor na svět i sebe samotného (Bloom, Petersen \& Kang, 2007). Podle Vorlíčka (2007) měřitelná definice kvality života (QOL) popisuje fyzické, funkční, psychické, sociální a duchovní zdraví onkologicky nemocné- 
ho jedince. Jde zejména o podmínky sociální, zdravotní, ekonomické a environmentální. Podle Glozmana (2004) jde v podstatě o tři skupiny faktorů: klinické, psychologické a sociodemografické. Do první skupiny řadí druh onemocnění, jeho stádium, délku trvání aj. Druhou skupinu zahrnují vztahy, které se vytvářejí v rodině, problémy související se zvládáním zátěží a dostupnosti péče o nemocného. Třetí skupinu faktorů tvoří věk pečovatele a nemocného, dosažené vzdělání, postavení pečovatele uvnitř rodiny, finanční zabezpečení rodiny aj. Vad'urová (2006) uvádí Aaronsonovu klasifikaci dimenzí kvality života týkající se zdraví (dimenze HRQOL), která má základní dimenze shodné s obecným chápáním kvality života. Rozlišuje tři hlavní dimenze HRQOL: dimenzi fyzickou, dimenzi psychologickou, sociální, spirituální, širší dimenzi.

Poměrně silně vnímají děti s OnOn nedostatek kontaktu se svými spolužáky a kamarády děti školního věku. Koutecký (1997) považuje začlenění dětí zpět do normálního života, do společnosti ostatních dětí a dospělých za prvořadý úkol sociální péče. Ve shodě s ostatními odborníky stejný autor také doporučuje, aby se děti účastnily všech vhodných volnočasových aktivit. Tato doporučení ve zvýšené míře platí v době po ukončení léčení. V této etapě se mohou vyléčené děti věnovat i pohybovým aktivitám a pohybovým hrám. Je samozřejmé, že míra intenzity bude záviset na charakteru onemocnění a léčby. Během času by se měla většina pacientů pohybovou aktivitou vyrovnat svým vrstevníkům. V rozporu s tímto názorem jsme svědky toho, že část rodičů svým dětem po onkologické léčbě brání ve fyzické aktivitě. V této souvislosti nutno zdůraznit nezastupitelné místo pohybových aktivit jako důležitého prostředku resocializace nemocných dětí (Martínková \& Hrstková, 2011).

V současné době se výzkum v oblasti děti a mládež s OnOn orientuje také na determinanty ovlivňujících životní způsob v rámci studie tzv. disHBSC (Health Behaviour in School Aged Children with disabilities). $\mathrm{V}$ rámci prípravy právě této studie byla realizována pilotní studie $\mathrm{s}$ cílem zjistit vybrané determinanty ovlivňující zapojení vybrané skupiny mládeže s onkologickým onemocněním do pohybových aktivit ve volném čase. 
Dílčím cílem bylo ověření modifikace standardizovaného dotazníku HBSC (Health Behaviour in School Aged Children) pro potřeby mládeže se speciálními potřebami (zejména zdravotním postižením a zdravotním znevýhodněním).

\section{METODIKA}

Ke zjištění vybraných determinant životního způsobu mládeže s onkologickým onemocněním jsme využili metody dotazovací, techniky dotazník disHBSC obsahující uzavřené otázky. U některých parametrů bylo využito škálování dle metodiky HBSC. Dotazník disHBSC je konstruován v souladu s dotazníkem HBSC v koordinaci s Lékařskou fakultou UPJŠ Košice a PdF UK Bratislava. Obsahuje 35 povinných otázek, 4 demografické, 5 volitelných a případně 5 národních.

Pilotního šetření se zúčastnilo celkem 18 osob (6 dívek a 12 chlapců) ve věku 11-15 let. Průměrný věk chlapců byl 12,9 a dívek 11,3.

\section{VÝSLEDKY}

V rámci našeho prezentovaného šetření a vydefinovaného cíle jsme se zaměřili na 6 vybraných otázek z 35 možných z kategorie povinné.

Tab. 1: Seznam di̊vodů, které dèti a mládež udávají pro účast na fyzické aktivitě ve svém volném čase (v\%)

\begin{tabular}{|l|l|l|l|l|}
\hline $\mathbf{n}=\mathbf{1 8}$ & $\begin{array}{l}\text { Velmi } \\
\text { důležité }\end{array}$ & Důležité & Nedůležité & $\begin{array}{l}\text { Celkem } \\
(\mathbf{v} \%)\end{array}$ \\
\hline Pohyb pro zábavu & 44 & 50 & 6 & 100 \\
\hline Být dobrý/á ve sportu & 44 & 44 & 11 & 100 \\
\hline Vyhrát & 6 & 22 & 72 & 100 \\
\hline $\begin{array}{l}\text { Seznámit se s novými } \\
\text { kamarády/kamarádkami }\end{array}$ & 33 & 50 & 17 & 100 \\
\hline
\end{tabular}


The way of living and selected determinants of children with oncological diseases Životní způsob a jeho vybrané determinanty u dětí s onkologickým onemocněním

\begin{tabular}{|l|l|l|l|l|}
\hline Zlepšit si svoje zdraví & 78 & 16 & 6 & 100 \\
\hline $\begin{array}{l}\text { Setkat se se svými } \\
\text { kamarády/kamarádkami }\end{array}$ & 28 & 72 & 0 & 100 \\
\hline $\begin{array}{l}\text { Dostat se do dobré } \\
\text { formy }\end{array}$ & 56 & 33 & 11 & 100 \\
\hline Vypadat dobře & 28 & 22 & 50 & 100 \\
\hline Radost z pohybu & 67 & 33 & 0 & 100 \\
\hline Potěšit moje rodiče & 44 & 39 & 17 & 100 \\
\hline Být “cool” & 6 & 50 & 44 & 100 \\
\hline $\begin{array}{l}\text { Udržovat si svoji } \\
\text { hmotnost }\end{array}$ & 50 & 33 & 17 & 100 \\
\hline Protože je to vzrušující & 6 & 50 & 44 & 100 \\
\hline
\end{tabular}

Jako nejdůležitější důvod ovlivňující zapojení nebo nezapojení do pohybových aktivit uvedli oslovení respondenti zlepšení zdraví, radost z pohybu a dostat se do formy (tab. 1). Při bližším pohledu na výsledky je patrné, že výrazně také přikládají důležitost pohybu pro zábavu, setkávání se svými stávajícími kamarády a dostání se do dobré formy. Je zde patrný akcent na zdravotní a sociální stránku.

Tab. 2: Seznam důvodů, které děti a mládež udávají pro účast na fyzické aktivitě ve svém volném čase (v\%)

\begin{tabular}{|c|c|c|c|c|c|}
\hline$n=18$ & $\begin{array}{l}\text { Nevěnuji } \\
\text { se této } \\
\text { činnosti }\end{array}$ & $\begin{array}{l}2 \times-3 \times \\
\text { měsíčně } \\
\text { a méně }\end{array}$ & $\begin{array}{l}\text { Asi } \\
\text { tak 1× } \\
\text { týdně }\end{array}$ & $\begin{array}{l}2 \times \\
\text { týdně } \\
\text { nebo } \\
\text { častěji }\end{array}$ & $\begin{array}{l}\text { Celkem } \\
(\mathrm{v} \%)\end{array}$ \\
\hline Fotbal & 61 & 11 & 17 & 11 & 100 \\
\hline
\end{tabular}




\begin{tabular}{|c|c|c|c|c|c|}
\hline Házenou & 56 & 17 & 28 & 0 & 100 \\
\hline $\begin{array}{l}\text { Basketbal nebo } \\
\text { jiné míčové hry }\end{array}$ & 28 & 17 & 33 & 22 & 100 \\
\hline Atletiku & 50 & 11 & 28 & 11 & 100 \\
\hline Gymnastiku & 83 & 17 & 0 & 0 & 100 \\
\hline Aerobic & 94 & 0 & 6 & 0 & 100 \\
\hline Běh, Jogging & 33 & 17 & 17 & 33 & 100 \\
\hline $\begin{array}{l}\text { Karate, Judo, } \\
\text { Taekwondo }\end{array}$ & 94 & 0 & 6 & 0 & 100 \\
\hline Zápas & 83 & 11 & 6 & 0 & 100 \\
\hline Box/Kickbox & 94 & 6 & 0 & 0 & 100 \\
\hline $\begin{array}{l}\text { Vzpírání/ } \\
\text { posilování }\end{array}$ & 50 & 22 & 11 & 17 & 100 \\
\hline $\begin{array}{l}\text { Tanec (disko, } \\
\text { techno, lidové } \\
\text { tance, balet) }\end{array}$ & 72 & 11 & 11 & 6 & 100 \\
\hline Skauting & 94 & 0 & 6 & 0 & 100 \\
\hline Plavání & 28 & 50 & 17 & 6 & 100 \\
\hline Cyklistiku & 11 & 39 & 39 & 11 & 100 \\
\hline Šplhání, rafting & 61 & 22 & 6 & 11 & 100 \\
\hline $\begin{array}{l}\text { Jízdu na } \\
\text { skateboardu, } \\
\text { kolečkových } \\
\text { bruslích }\end{array}$ & 50 & 22 & 22 & 6 & 100 \\
\hline $\begin{array}{l}\text { V létě: turistiku, } \\
\text { rybaření }\end{array}$ & 56 & 22 & 17 & 6 & 100 \\
\hline
\end{tabular}


The way of living and selected determinants of children with oncological diseases

\begin{tabular}{|l|l|l|l|l|l|}
\hline $\begin{array}{l}\text { V létě: vodní } \\
\text { aktivity (plavání, } \\
\text { surfování, vodní } \\
\text { lyžování) }\end{array}$ & 11 & 22 & 33 & 33 & 100 \\
\hline $\begin{array}{l}\text { V zimě: bruslení, } \\
\text { hokej }\end{array}$ & 17 & 33 & 44 & 6 & 100 \\
\hline Zpěv ve sboru & 89 & 0 & 6 & 6 & 100 \\
\hline $\begin{array}{l}\text { Hru na hudební } \\
\text { nástroj v dechové } \\
\text { kapele nebo } \\
\text { orchestru }\end{array}$ & 72 & 0 & 22 & 6 & 100 \\
\hline $\begin{array}{l}\text { Zpěv, hru v kapele } \\
\text { (popové, rockové) }\end{array}$ & 89 & 0 & 11 & 0 & 100 \\
\hline $\begin{array}{l}\text { Individuální lekce } \\
\text { hudby }\end{array}$ & 94 & 6 & 0 & 0 & 100 \\
\hline $\begin{array}{l}\text { Hru v divadle / } \\
\text { show }\end{array}$ & 94 & 0 & 6 & 0 & 100 \\
\hline $\begin{array}{l}\text { Aktivity } \\
\text { v církevním } \\
\text { společenství }\end{array}$ & 100 & 0 & 0 & 0 & 100 \\
\hline
\end{tabular}

Mezi aktivity (tab. 2), kterým se věnují respondenti minimálně $2 \times$ týdně patří zejména vodní aktivity, běhání a míčové hry. Mezi aktivity, kterým se nevěnují, nebo věnují minimálně, jsou aktivity v církevních společenstvech, hudebním a dramatickým aktivitám, skautingu, kondičním cvičením, úpolovým aktivitám a gymnastice.

Zároveň při analýze této otázky vyvstala potřeba otázku pro oficiální výzkumné šetření disHBSC přeformulovat (viz dílčí cíl).

Vzhledem WHO se pohybových aktivit účastní v minimální doporučené době (min. 3 dny v týdnu) věnuje pohybových aktivitám 66 \% dívek a více než $90 \%$ chlapců (obr. 1). Nejvíce se pohybovým aktivitám v týdenním režimu věnují starší respondenti, zejména 15letí (obr. 2). 


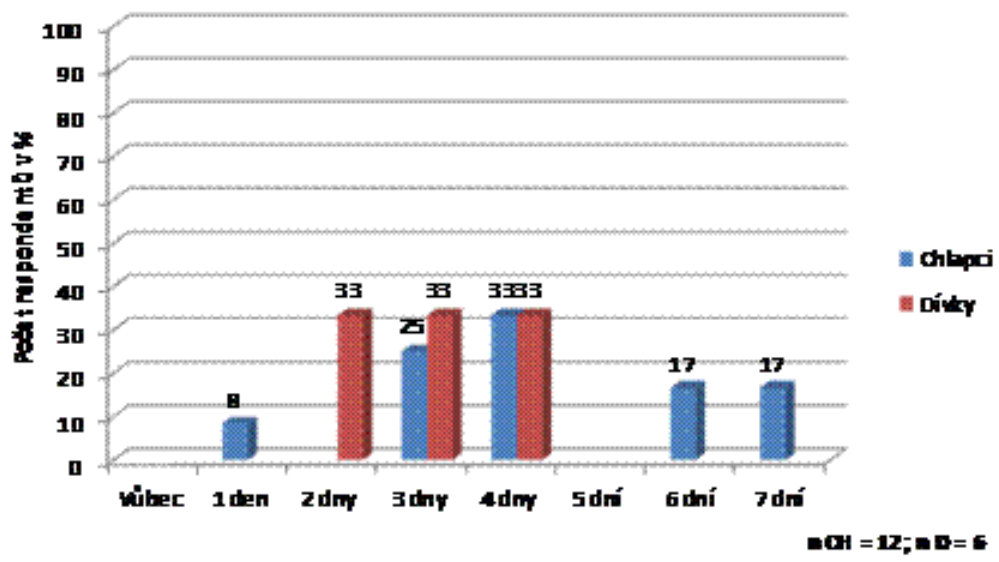

Obr. 1: V kolika dnech z uplynulých 7 dnů ses věnoval fyzické aktivitě celkem alespoň 1 hod. za celý den? (z hlediska pohlaví)

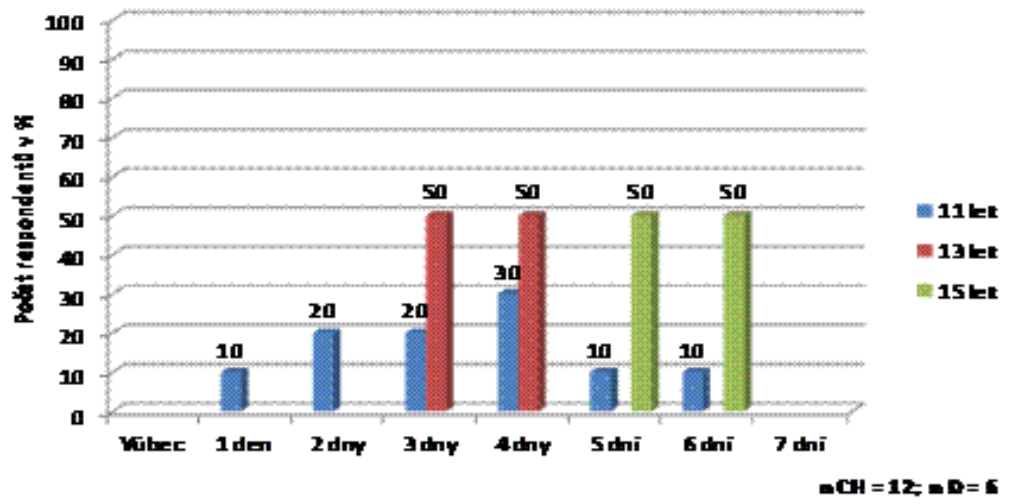

Obr. 2: V kolika dnech z uplynulých 7 dnů ses věnoval fyzické aktivitě celkem alespoň 1 hod. za celý den? (z hlediska věku) 
Za alarmující můžeme považovat to, že navzdory doporučení 50 \% patnáctiletých je osvobozeno od školní TV (obr. 3). Avšak podobně jako formulace $\mathrm{v}$ tab. 2 je nutné i tuto otázku změnit $\mathrm{z}$ důvodu nepochopení respondentů a zároveň ne př́liš št’astně vybraným parametrům.

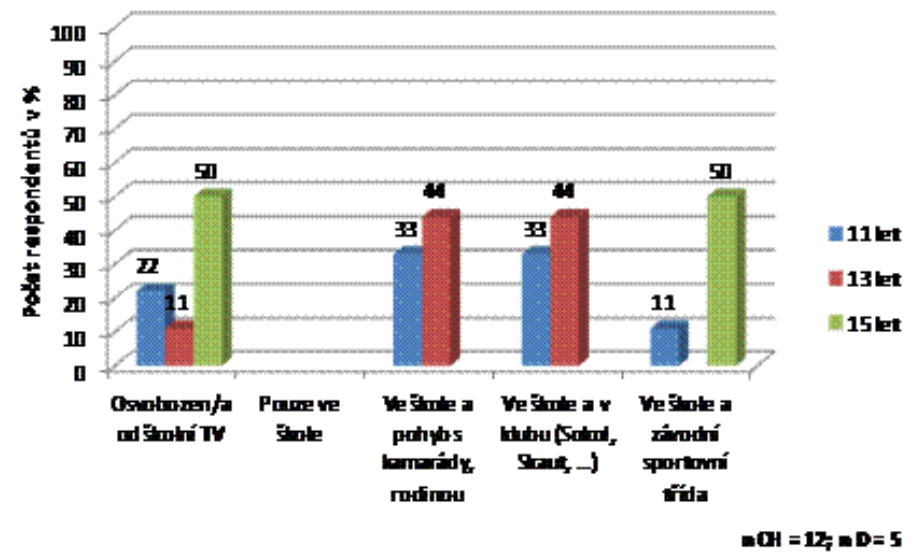

Obr. 3: Jakou formou provozuješ pohybové aktivity? (z hlediska věku)

\section{ZÁVĚR}

Z vybraných dílčích výsledků pilotního šetření je patrný zájem o pohybové aktivity ve volném čase u mládeže s onkologickým onemocněním. Navzdory tomu je systematicky znemožňován přístup řady z nich osvobození ze školní tělesné výchovy. Přesto se ve volném čase pohybovým aktivitám věnují zejména díky tomu, že se s různými pohybovými aktivitami respondenti setkali již před nástupem nemoci v rámci školní TV i volnočasových aktivit.

Pilotní šetření realizované u skupiny mládeže s onkologickým onemocněním v období remise nám odhalilo několik nepřesností, chyb a pro pochopení složitých formulací. Doporučení byla zohledněna při konstrukci oficiálního dotazníku, který bude aplikován v druhé polovině roku 2013 a v průběhu roku 2014. 


\section{LITERATURA}

Bloom J. R., Petersen D. M., \& Kang S. H. (2007). Multi-dimensional quality of life among long-term (5+ years) adult cancer survivors. Psycho-Oncology, 16, 691-706.

Glozman, J. M. (2004). Quality of Life of Caregivers. Neuropsychology Review, 14 (4), 183-196.

Koutecký, J. (1997). Nádorová onemocněni dětí a mladistvých. Praha: Karolinum.

Martinková, S., \& Hrstková, H. (2011). Zvyšování kvality života dětí $\mathrm{s}$ onkologickým onemocněním prostřednictvím programů zaměřených na pohybové aktivity. In A. Vyskočilová (ed.). Sborník př́spěvku 1. České národní konference aplikovaných pohybových aktivit (pp. 26). Olomouc: UP v Olomouci.

Nadační fond dětské onkologie KRTEK. (2007). Klinika dětské onkologie fakultni nemocnice Brno. Retrieved 22. 1. 2010 from the World Wide Web: http://www.krtek-nf.cz.

Vad’urová, H. (2006). Sociální aspekty kvality života v onkologii. Brno: MSD.

Vorlíček, J. (2007). Kvalita života v onkologii - o čem je řeč? Př́spévek na symposiu „Česká onkologická společnost“. Rajhrad, Česká republika.

\section{KONTAKT:}

Mgr. Tomáš Vyhlídal, vyhlidal.apa@upol.cz 